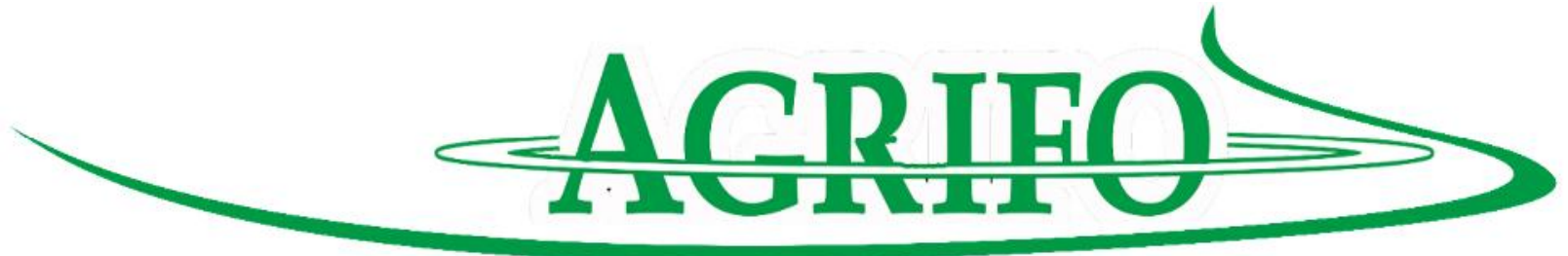

\title{
FAKTOR-FAKTOR YANG MEMPENGARUHI PRODUKSI GARAM DI DESA MATANG TUNONG
}

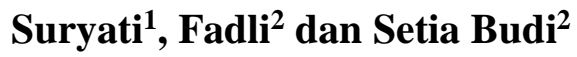 \\ ${ }^{1}$ Program Studi Agribisnis Fakultas Pertanian \\ ${ }^{2}$ Staff Pengajar Prodi Agribisnis Universitas Malikussaleh
}

\begin{abstract}
ABSTRAK
Penelitian ini bertujuan untuk mengetahui faktor-faktor yang mempengaruhi produksi garam di Desa Matang Tunong Kabupaten Aceh Utara. Metode penelitian ini menggunakan pendekatan kuantitatif. Hasil penelitian menunjukkan bahwa nilai determinasi $\left(\mathrm{R}^{2}\right)$ adalah 0,919 berarti $91,9 \%$ luas lahan $\left(\mathrm{X}_{1}\right)$, bibit garam $\left(\mathrm{X}_{2}\right)$, tenaga kerja $\left(\mathrm{X}_{3}\right)$, mampu menjelaskan variasi produksi garam, sedangkan sisanya 9,59\% lagi diterangkan oleh variabel lain di luar model. Bibit garam $\left(\mathrm{X}_{2}\right)$ berpengaruh nyata terhadap pendapatan petani garam $(\mathrm{Y})$ karena nilai signifikan t lebih kecil dari alpha yaitu $0,000<0,01$. Koefisien regresi sebesar 0.687, dapat diartikan bahwa penambahan bibit garam sebesar $1 \mathrm{~kg}$ maka akan meningkatkan produksi petani garam sebesar Rp. 0.687 , rata-rata petani garam menggunakan bibit garam sebanyak $23 \mathrm{~kg}$.
\end{abstract}

Kata Kunci : Produksi, Faktor Produksi dan Garam

\section{PENDAHULUAN}

Kabupaten Aceh Utara merupakan daerah yang cukup potensial untuk perkembangan usaha pembuatan garam yang dapat menciptakan lapangan kerja bagi masyarakat yang tinggal di daerah ini. Daerah-daerah penghasil garam di Aceh Utara yaitu terdiri dari Kecamatan Dewantara, Syamtalira Bayu, Lapang dan Kecamatan Seunuddon. Berdasarkan data yang diperoleh dari Dinas Kelautan dan Perikanan Aceh Utara tahun 2014, Kabupaten Aceh Utara memiliki lahan potensi garam seluas $167 \mathrm{Ha}$ yang tersebar di beberapa Kecamatan yaitu Kecamatan Dewantara, Syamtalira Bayu, Lapang dan Seunuddon.

Garam dihasilkan dari desa di Kecamatan Lapang Kabupaten Aceh Utara untuk memenuhi kebutuhan masyarakat. Petani garam tradisional di Aceh Utara saat ini belum mampu menghasilkan garam beryodium. Padahal harga garam beryodium lebih mahal dibandingkan garam alami. Meskipun petani garam di Kabupaten Aceh Utara kurang dari 300 orang, 
namun mereka masih menghasilkan garam alami. Sementara garam beryodium yang dipasarkan di

Lhokseumawe dan sekitarnya dipasok dari luar daerah. Usaha garam selama ini sudah menjadi sumber pendapatan warga pesisir Aceh Utara, untuk kebutuhan keluarga, saat ini harga garam di Kecamatan Lapang yang dijual kepada agen atau pengumpul hanya berkisar Rp. 2.000 s/d Rp. 3.000 perkilogram. Kwalitas garam juga sangat baik masuk kategori kualitas 1 (K1). Namun, para pengepul garam petani dihargai murah dibawah ketentuan pemerintah yaitu $\mathrm{Rp} 750$ perkilogram untuk garam K1 dan Rp 550 perkilogram untuk garam K2 dan sekarang K1 Rp 350, K2 Rp 300 perkilogram. Berikut data perkembangan harga garam di Kecamatan Lapang selama 5 tahun terakhir.

Garam yang diproduksi di Kecamatan Lapang tergantung pada kondisi musim penggaraman. Pada saat musim kemarau, produksi garam meningkat sehingga menyebabkan harga garam menjadi turun (DKP Aceh Utara, 2014)
Tujuan penelitian ini adalah untuk mengetahui faktor-faktor yang mempengaruhi produksi garam di Desa Matang Tunong Kabupaten Aceh Utara.

\section{METODE PENELITIAN}

Penelitian ini dilakukan di Desa Matang Tunong Kecamatan Lapang Kabupaten Aceh Utara. Pemilihan lokasi dilakukan secara sengaja dengan pertimbangan Desa Matang Tunong merupakan penghasil Garam di Kecamatan Lapang. Ruang lingkup penelitian ini dibatasi pada faktor-faktor yang mempengaruhi produksi garam rakyat yaitu luas lahan, bibit garam dan tenaga kerja di Desa Matang Tunong Kecamatan Lapang Kabupaten Aceh Utara.

Data yang diperoleh dari lapangan, dikumpulkan dan dianalisis dengan menggunakan fungsi produksi Cobb-Douglass. Secara matematik, fungsi Cobb-Douglass dapat ditulis sebagai berikut (Fauziyah, 2010).

$$
\begin{aligned}
\mathrm{Y} & =\mathrm{a} X 1^{\mathrm{b} 1} \mathrm{X} 2^{\mathrm{b} 2} \ldots \mathrm{X} 1^{\mathrm{bi}} \ldots \mathrm{X}_{\mathrm{n}}^{\mathrm{bn}} \mathrm{e}^{\mathrm{u}} \\
& =\mathrm{a} \Pi \mathrm{X}_{\mathrm{n}}^{\mathrm{bn}} \mathrm{e}^{\mathrm{u}}
\end{aligned}
$$


Untuk mempermudahkan perhitungan dari fungsi tersebut kemudian diubah dalam bentuk logaritma linier, sehingga persamaan matematisnya menjadi:

$\log \mathrm{Y}=\log \mathrm{a}+\mathrm{b}_{1} \log \mathrm{X}_{1}+\mathrm{b}_{2} \log \mathrm{X}_{2}$ $+\mathrm{b}_{3} \log \mathrm{X}_{3}+\mathrm{e}$

Keterangan :

Y : Tingkat produksi garam

a : Konstanta

bi : Parameter estimasi

$\mathrm{X}_{1} \quad$ : Luas Lahan (Ha)

$\mathrm{X}_{2} \quad$ : Bibit Garam (Kg)

$\mathrm{X}_{3} \quad$ : Tenaga Kerja

e : error term

\section{Uji Asumsi Klasik}

\section{a. Uji Normalitas}

Uji normalitas bertujuan untuk menguji apakah dalam regresi, variabel terikat (dependen) dan variabel bebas (independen) memiliki distribusi normal atau tidak. Untuk mengetahui model regresi yang baik yaitu apabila variabel-variabel yang diteliti mempunyai distribusi normal atau mendekati normal. Uji normalitas bisa dilakukan dengan dua cara, yaitu dengan Normal P-P Plot dan tabel Komogorov Smirnov yang paling umum digunakan adalah Normal P-P Plot.

\section{b. Uji Multikolinieritas}

Mulitikolinieritas dalam model dapat dilihat dari nilai Variance Inflation Factor (VIF) pada masingmasing variabel bebasnya. Jika nilai VIF kurang dari 10, maka menunjukkan bahwa persamaan tersebut tidak mengalami masalah multikolinieritas yang serius.

Sebaliknya jika nilai VIF peubah bebasnya lebih besar dari 10, maka menunjukkan persamaan tersebut mengalami masalah multikolinieritas yang serius.

c. Uji Heteroskedastisitas

Bertujuan menguji apakah dalam model regresi terjadi ketidaksamaan varians dari residual satu pengamatan ke pengamatan yang lain. Model regresi yang baik yaitu homoskesdatisitas atau tidak terjadi heteroskedastisitas.Untuk mendeteksi ada tidaknya heteroskedastisitas yaitu dengan melihat scatter plot (nilai 
prediksi dependen ZPRED dengan residual SRESID) yang dikenal dengan metode grafik yaitu: memplotkan ui $^{2}$ dan $\hat{Y}$ i. Heteroskedastisitas akan terdeteksi bila plot menunjukkan pola yang sistematis (Gujarati \& Porter, 2003).

\section{PEMBAHASAN}

\section{Penggunaan}

Faktor-Faktor

\section{Produksi}

$$
\text { Penggunaan faktor - faktor }
$$

produksi dalam penelitian ini pada usaha garam meliputi luas lahan, bibit dan tenaga kerja

a. Luas Lahan

Salah satu faktor yang mempengaruhi tingkat produksi Garam adalah luas lahan. Petani Garam di daerah penelitian, umumnya melakukan usaha garam pada lahan milik sendiri (Febrina \& Liana, 2008). Luas lahan yang digunakan tiap petani untuk usahatani garam di lokasi penelitian cukup beragam yaitu dari $0,023 \mathrm{Ha}$ hingga $0.067 \mathrm{Ha}$ dan rata-rata luas lahan di daerah penelitian yaitu 0,0444 Ha.

b. Bibit garam
Petani Garam dilokasi penelitian memproduksi garam dengan menggunakan garam pancing atau bibit garam yang diperoleh dari Madura. Bibit garam dibeli oleh petani dengan harga Rp. 6.000/sak atau $50 \mathrm{~kg} / \mathrm{sak}$. Dalam kali pemasakan garam biasanya petani menggunakan $40 \mathrm{~kg}$ bibit untuk satu kali proses produksi yang dimasak menggunakan air laut, agar garam yang dihasilkan lebih halus karena bibit garam dari Madura bertekstur kasar dengan butiran-butiran yang menyerupai kerikil. Dalam satu bulan rata-rata bibit garam yang digunakan oleh petani garam ditempat penelitian adalah $3253,33 \mathrm{~kg}$.

c. Tenaga Kerja

Jumlah tenaga kerja yang dipekerjaka dalam industri tradisional ini tidak banyak. Paling sedikit satu orang dan paling banyak dua orang. Dari hasil penelitian dapat disimpulkan bahwa jumlah pekerja dalam industri tradisional garam yang paling banyak 23057 HOK dan paling rendah 10286 HOK. Para pekerja ini berasal dari berasal dari keluarga sendiri. Biasanya istri, suami 
atau juga anak ikut bekerja membantu pembuatan garam. Semakin banyak tenaga kerja yang digunakan maka akan sangat berpengaruh terhadap produksi garam.

\section{Analisis Faktor - faktor yang} Mempengaruhi Produksi Garam

Peningkatan produksi garam garam dalam meningkatkan pendapatan petani dan menuju peningkatan kesejahteraan keluarga, sekaligus meningkatkan pendapatan nasional (Gunawan, 2013). Dalam rangka meningkatkan hasil produksi usahatani garam dibutuhkan faktorfaktor pendukung seperti luas lahan $\left(\mathrm{X}_{1}\right)$, bibit garam $\left(\mathrm{X}_{2}\right)$, tenaga kerja $\left(\mathrm{X}_{3}\right)$, dengan menggunakan fungsi produksi Cobb Douglas. Hasil analisis regresi dapat dilihat pada Tabel 7 berikut. merupakan salah satu usaha petani Tabel. 7. Hasil Analisis Regresi Pendugaan Faktor-faktor yang Mempengaruhi Produksi Garam di Desa Matang Tunong Kecamatan Lapang Kabupaten Aceh Utara

\begin{tabular}{|c|c|c|c|c|c|}
\hline \multirow{2}{*}{ Model } & \multicolumn{2}{|c|}{ Unstandardized Coefficients } & $\begin{array}{c}\text { Standardized } \\
\text { Coefficients }\end{array}$ & \multirow{2}{*}{$\mathbf{t}$} & \multirow{2}{*}{ Sig. } \\
\hline & B & Std. Error & Beta & & \\
\hline Constant) & 1.752 & 0.924 & & 0.896 & 0.069 \\
\hline $\mathrm{X}_{1}$ & -0.032 & 0.74 & 0.071 & 0.466 & 0.645 \\
\hline $\mathrm{X}_{2}$ & 0.537 & 0.147 & 0.611 & 0.645 & 0.001 \\
\hline $\mathrm{X}_{3}$ & -0.035 & 0.142 & 0.041 & 0.249 & 0.805 \\
\hline $\mathrm{R}=0.646^{\mathrm{a}}$ & \multicolumn{5}{|c|}{$F_{\text {hitung }}=6.196$} \\
\hline $\mathrm{R}^{2}=0.417$ & \multicolumn{5}{|c|}{$\mathrm{F}_{\text {sig }}=0.003$} \\
\hline
\end{tabular}

Sumber: Data Diolah

Diperoleh persamaan sebagai berikut: $\mathrm{Y}=1.752+-0.032 \mathrm{X}_{1}+0.537 \mathrm{X}_{2}+-$ $0.035 \mathrm{X}_{3}$
Analisis regresi pada Tabel 7 menunjukkan bahwa nilai determinasi $\left(\mathrm{R}^{2}\right)$ adalah 0,417 berarti $41,7 \%$ luas 
lahan $\left(X_{1}\right)$, bibit garam $\left(X_{2}\right)$, tenaga kerja $\left(\mathrm{X}_{3}\right)$, mampu menjelaskan variasi produksi garam, sedangkan 78 sisanya $64,6 \%$ lagi diterangkan oleh variabel lain di luar model. Koefisien korelasi (R) diperoleh sebesar $0.64 \%$ berarti bahwa luas lahan, bibit garam dan tenaga kerja berhubungan kuat dengan produksi garam di Desa Matang Tunong Kecamatan Lapang Kabupaten Aceh Utara.

Hasil uji koefisien secara serempak (Uji F) dilakukan untuk melihat pengaruh variabel independen terhadap variabel dependen. Secara statistik di peroleh nilai signifikan $\mathrm{F}$ sebesar 0.003 hasil tersebut menunjukkan signifikan $\mathrm{F}$ lebih kecil dari $\alpha(0.05)$ yang berarti bahwa secara serempak luas lahan, bibit garam dan tenaga kerja berpengaruh sangat signifikan terhadap produksi garam.

Luas lahan $\left(\mathrm{X}_{1}\right)$ tidak berpengaruh signifikan terhadap produksi Garam didaerah penelitian karena nilai signifikanya lebih besar dari alpha (0.069 > 0.05). Rata-rata luas lahan di daerah penelitian 0.0444 .
Penggunaan bibit garam $\left(\mathrm{X}_{2}\right)$ berpengaruh nyata terhadap pendapatan petani garam $(\mathrm{Y})$ karena nilai signifikan $t$ lebih kecil dari alpha yaitu $0,001<0,05$. Koefisien regresi sebesar 0.537, dapat diartikan bahwa penambahan bibit garam sebesar $1 \mathrm{~kg}$ maka akan meningkatkan produksi petani garam sebesar Rp. 0.537, ratarata petani garam menggunakan bibit garam sebanyak $3.253,33 \mathrm{~kg}$.

Penggunaan tenaga kerja $\left(\mathrm{X}_{3}\right)$ tidak berpengaruh signifikan terhadap produksi garam (Y) ditunjukkan oleh nilai signifikan $t$ lebih besar dari alpha yaitu $\quad 0.805>0.05$. Tidak signifikannya variabel tenaga kerja terhadap produksi garam dikarenakan dalam proses produksi garam tidak banyak dibutuhkan pada saat pengangkutan air laut dari tambak atau tempat penampungan untuk di masak dan proses pemasakan.

\section{KESIMPULAN}

Berdasarkan hasil penelitian yang telah dilakukan, maka dapat disimpulkan bahwa:

1. Nilai determinasi $\left(\mathrm{R}^{2}\right)$ adalah 0,417 berarti $41,7 \%$ luas lahan 
$\left(\mathrm{X}_{1}\right)$, bibit garam $\left(\mathrm{X}_{2}\right)$, tenaga kerja $\left(\mathrm{X}_{3}\right)$, mampu menjelaskan variasi produksi garam, sedangkan sisanya $64,6 \%$ lagi diterangkan oleh variabel lain di luar model.

2. Bibit garam $\left(\mathrm{X}_{2}\right)$ berpengaruh nyata terhadap pendapatan petani garam (Y) karena nilai signifikan $\mathrm{t}$ lebih kecil dari alpha yaitu 0,001 $<0,05$. Koefisien regresi sebesar 0.537, dapat diartikan bahwa penambahan bibit garam sebesar $1 \mathrm{~kg}$ maka akan meningkatkan produksi petani garam sebesar Rp. 0.537, rata-rata petani garam menggunakan bibit garam sebanyak $3.253,33 \mathrm{~kg}$.

\section{DAFTAR PUSTAKA}

Fauziyah, E. (2010). Analisis Efisiensi Teknis Usahatani Tembakau (Suatu Kajian dengan Menggunakan Fungsi Produksi Frontier Stochastic). Jurnal Embryo, 7(1), 1-7.

Febrina, D., \& Liana, M. (2008). Pemanfaatan limbah pertanian sebagai pakan ruminansia pada peternak rakyat di Kecamatan Rengat Barat Kabupaten Indragiri Hulu. Jurnal Peternakan, 5(1).

Gujarati, D. N., \& Porter, D. C. (2003). Basic Econometrics. 4th. New York: McGraw-Hill.

Gunawan, I. (2013). Metode penelitian kualitatif. Jakarta: Bumi Aksara. 